\title{
The Effect of Egg Yolk Oil on The Chemical, Physical and Sensory Properties of Mayonnaise
}

\author{
*Aleksandrs Kovalcuks, Evita Straumite, Māra Duma \\ Latvia University of Agriculture, Lielā street 2, Jelgava, LV-3001, Latvia
}

\begin{abstract}
Egg yolk oil (EYO) is an essence of egg bioactive compounds. Extracted from egg yolk it can be used in various food products increasing their nutritional and biological value. Mayonnaise is a kind of a semi-solid oil-inwater emulsion containing 60-80\% fat. Mayonnaise typically contains oil, egg yolk, vinegar, salt, sugar and thickening agents. Mayonnaise is the product where application of EYO can be evaluated. The aim of this study was to evaluate the effect of egg yolk oil on the chemical, physical and sensory properties of mayonnaise. EYO was added to mayonnaise in the concentrations of $1,3,5$ and $7 \%$. The main parameters of mayonnaise were determined using standard methods: lipid, protein, fatty acids, vitamin $\mathrm{D}, \mathrm{pH}$, viscosity, colour and acceptance of sensory properties (viscosity, egg aroma, egg taste, yellow colour, sour taste and creaminess). At analyzed concentrations EYO has no influence $(\mathrm{p}>0.05)$ on mayonnaise $\mathrm{pH}$, lipid and protein content, but an increase in EYO content decreases the viscosity of mayonnaise. Increasing amount of EYO additive resulted in more intensive yellow colour of mayonnaise. Additions of EYO enrich mayonnaise with vitamin D and docosahexaenoic acid. Sensory evaluation of mayonnaise samples showed panellists' preference for mayonnaise with 3\% and 5\% EYO additive.
\end{abstract}

Keywords: egg yolk oil, mayonnaise, physical properties, sensory evaluation.

\section{Introduction}

Chicken eggs are widely used in different food products for nutritional and functional needs. Eggs are a very good source of main nutrients such as proteins, fats, minerals and others. Moreover, all these nutrients are well balanced to meet human needs in healthy diet (Egg nutritional council, 2014). The high egg nutritional value corresponds to egg proteins, which are nearer $100 \%$ bioavailable and contain all essential amino acids (Layman \& Rodriguez, 2009). In case of biological value, most of bioactive compounds, such as polyunsaturated fatty acids, oil soluble vitamins, pigments, phospholipids and sterols, are located in the egg yolk (Huopalahti, Lopez-Fandino, Anton \& Schade, 2007). As functional properties of eggs - foaming, emulsifying and thickening can be mentioned (Alleoni, 2006; Huopalahti, Lopez-Fandino, Anton \& Schade, 2007; Stadelman, 1999). Apart from functional and nutritional properties, eggs supply food products with specific egg flavor. In many products, like mayonnaise, dressings, egg noodles, bakery goods, rich and intensive egg flavor is considered as a benefit. But egg application in food can be limited by individual allergy for egg proteins.

Egg proteins are well-known allergen, especially for children (Tan \& Joshi 2014). To replace eggs in food products, egg flavorings and thickeners are used. But flavorings give only the taste and smell of egg but do not supply food with nutrients and bioactive compounds. In this case egg yolk oil can be very appropriate alternative which provides both flavor and bioactive compounds. Egg yolk oil contains oil soluble vitamins, such as vitamins A, D, E, unsaturated and polyunsaturated fatty acids and carotenes of egg yolk in a concentrated way. The high level of bioactive compounds and intensive colour of egg yolk oil can allow using it in low dosages to enrich food products with egg nutrients and flavor. Deficiency of bioactive compounds in food is related to many health problems and chronic deceases (Holick, 2007). There are vegetable sources of oil soluble vitamins and polyunsaturated fatty acids, but some of bioactive compounds, such as vitamin D and sterols, are provided only by animal based products (Schmid \& Walther, 2013).

Mayonnaise is the product where application of egg yolk oil can be evaluated. Mayonnaise is an oilin-water emulsion with fat content from 60 to $80 \%$ (it differs from country to country and local legislation). Besides eggs and oil, mayonnaise typically contains mustard, vinegar, salt, sugar and thickening agents. Mayonnaise is widely used in preparation of many 
dishes and consumed by humans of any ages, from kids to seniors. In mayonnaise production, three properties of eggs are usually required: functionality, taste and nutritional value. Functional properties of eggs are carried by egg proteins and phospholipids (Alleoni, 2006; Schneider, 2001; Stadelman, 1999). As egg yolk oil does not contain egg proteins, the application of egg yolk oil is limited by nutritional and sensorial properties. Functional properties of eggs can be compensated by other ingredients (Herald, Abugoush \& Aramoouni, 2009). The taste, viscosity, appearance and creaminess of mayonnaise are very important sensory properties, which determine consumer's choice and preferences. Mayonnaise enrichment with egg yolk oil bioactive compounds also must have positive effect on consumer choice.

The aim of this study was to evaluate the effect of egg yolk oil on the chemical, physical and sensory properties of mayonnaise.

\section{Materials and Methods}

Experiments were carried out at the World's Poultry Scientific Association Latvia Branch scientific laboratory and Faculty of Food Technology laboratories, Latvia University of Agriculture.

\section{Egg Yolk Oil Extraction}

For experiments, egg yolk oil was obtained by solvent extraction from fresh liquid egg yolks using the method elaborated by Kovalcuks (2014). Homogenized liquid egg yolk was added to ethanol and stirred until egg yolk proteins denatured and completely dispersed. Then, the mixture was filtered by vacuum filtration, and the supernatant was collected and transferred to a separatory funnel. The precipitate was extracted with hexane. The hexane extract was filtered by vacuum filtration and supernatant was collected and added to the same separatory funnel. Both ethanol and hexane extracts were thoroughly but gently, to avoid emulsion formation, mixed to extract polar lipids and impurities to a polar ethanol-water phase and neutral lipids to a non-polar hexane phase. After that, the mixed extracts were left for 1 hour for phase separation. Bottom ethanol/water layer, containing polar lipids and water soluble compounds were drained from the separatory funnel through the open stopcock. Hexane extract was collected in a clean container. Egg yolk oil was obtained from the hexane extract by evaporation of the hexane in the rotary evaporator. After solvent evaporation, pure nitrogen gas was laid through the egg oil for the removal of solvent traces.

\section{Materials for mayonnaise}

Mayonnaise was made using refined sunflower oil (JSC Efko, Russia), sugar (Ltd. Nordic Sugar, Denmark), salt (Ltd. Voldemars, Latvia), modified potato starch Trecomex Twelve 02 (Culinar Polska Sp. Z o.o, Poland), lactose free skimmed milk powder (SMP) (Ltd. Valio, Finland), xanthan gum (CP Kelco, Poland), 9\%vinegar (Ltd. Ilgezeem, Latvia), mustard powder (Ltd. Valezs, Latvia), egg yolk powder (JSC Balticovo, Latvia) and drinking water.

\section{Preparation of mayonnaise}

The mayonnaise was made using recipes presented in Table 1.

Recipes for mayonnaise with egg yolk oil (EYO) addition, \% w/w

Table 1

\begin{tabular}{|c|c|c|c|c|c|}
\hline \multirow[t]{2}{*}{ Ingredients } & \multicolumn{5}{|l|}{ Samples } \\
\hline & Control & \begin{tabular}{|l} 
EYO \\
$1 \%$
\end{tabular} & $\begin{array}{l}\text { EYO } \\
3 \%\end{array}$ & \begin{tabular}{|l} 
EYO \\
$5 \%$
\end{tabular} & $\begin{array}{l}\text { EYO } \\
7 \%\end{array}$ \\
\hline Sunflower oil & \begin{tabular}{|l|}
60.0 \\
\end{tabular} & 59.0 & \begin{tabular}{|l|}
57.0 \\
\end{tabular} & 55.0 & \begin{tabular}{|l|}
53.0 \\
\end{tabular} \\
\hline Egg yolk oil & - & 1.0 & 3.0 & 5.0 & 7.0 \\
\hline Modified starch & - & 0.3 & & & \\
\hline Water & 29.8 & 30.5 & & & \\
\hline Egg yolk powder & 1 & - & & & \\
\hline Sugar & \multicolumn{5}{|l|}{2.5} \\
\hline Salt & \multicolumn{5}{|l|}{1.0} \\
\hline Lactose free SMP & \multicolumn{5}{|l|}{1.0} \\
\hline Xanthan gum & \multicolumn{5}{|l|}{0.2} \\
\hline Vinegar 9\% & \multicolumn{5}{|l|}{4.0} \\
\hline Mustard powder & \multicolumn{5}{|l|}{0.5} \\
\hline Total & \multicolumn{5}{|l|}{100.0} \\
\hline
\end{tabular}


The mayonnaise was prepared using a blender Bosch MMB 1001 (Robert Bosch GmbH, Germany). Sugar, salt, lactose free skimmed milk powder, mustard powder and egg yolk powder (in control recipe) were mixed in water and homogenized for 1 minute. The modified starch and xanthan gum were dispersed in sunflower oil in ratio 1:3 and then added to water phase at the low mixing speed (700 rpm $\mathrm{min}^{-1)}$. Mixture was left for 5 minutes for swelling of starch and xanthan gum. Egg yolk oil was diluted in sunflower oil and added with a thin squirt to a blender operated on full speed. After all oil was added the emulsification process was continued for 120 seconds. As a final step, vinegar was added to the mayonnaise and homogenized for 30 seconds (AbuSalem \& Abou-Ara, 2008; Amin, Elbeltagy, Mustafa \& Khalil, 2014; Karas, Skvarča \& Žlender, 2002).

\section{Chemical and physical analysis}

$p H$. The $\mathrm{pH}$ of mayonnaise samples was measured directly using a $\mathrm{pH}$ meter InoLab ${ }^{\circledR} \mathrm{pH} 7110$ with IDS
pH electrode SenTix ${ }^{\circledR} 950$ (WTW WissenschaftlichTechnische Werkstätten GmbH, Germany). pH meter calibration was made in accordance with the internal lab standard. The results were the mean of three replicates.

Colour analysis. Colour of mayonnaise samples was determined using the CIE $\mathrm{L}^{*} \mathrm{a}^{*} \mathrm{~b}^{*}$ scale with the ColorTec-PCM colorimeter (ColorTec Associates, Inc., USA) and ColorSoft QCW program for data processing. Before measuring, the colorimeter was calibrated using a white reference tile and a light trap (black tile). The measured colour parameters were lightness $\left(\mathrm{L}^{*}\right)$, the degree of redness or greenness $\left(a^{*}\right)$, degree of blueness or yellowness $\left(b^{*}\right)$. The ColorTec-PCM colorimeter measured the reflectance of light from a mayonnaise samples filled till top in plastic plates and covered with lids. The $\mathrm{L}^{*} \mathrm{a}^{*} \mathrm{~b}^{*}$ values were presented as the mean of seven replicates. To quantify colour difference between the samples, $\Delta \mathrm{E}$ was calculated using formula 1 (Joint ISO/CIE Standard, 2007).

$$
\Delta E_{a b}^{*}=\sqrt{\left(L_{2}^{*}-L_{1}^{*}\right)^{2}+\left(a_{2}^{*}-a_{1}^{*}\right)^{2}+\left(b_{2}^{*}-b_{1}^{*}\right)^{2}}
$$

where:

$\mathrm{L}_{2}{ }^{*}, \mathrm{a}_{2}{ }^{*}, \mathrm{~b}_{2}{ }^{*}-$ measured values of mayonnaise with $1 \%, 3 \%, 5 \%$ and $7 \%$ of egg yolk oil

$\mathrm{L}_{1}{ }^{*}, \mathrm{a}_{1}{ }^{*}, \mathrm{~b}_{1}{ }^{*}-$ measured values of control sample mayonnaise

Viscosity. Viscosity of mayonnaise samples was measured by using Rotational Rheometer RheolabQC Anthon Paar (Anton Paar GmbH, Austria) with a spindle $\mathrm{CC} 27$ at temperature $21 \pm 1^{\circ} \mathrm{C}$ and rotation speed $500 \mathrm{~s}^{-1}$. The mayonnaise sample was filled in viscosity measuring cup till a mark, as mentioned in Rheometer RheolabQC users' manual, and viscosity data were recorded.

Fatty acids. Fatty acids were determined in accordance with the standard methods ISO 12966-2 (ISO, 2011) and ISO 5508 (ISO, 1990), GC-FID (gas chromatography with flame ionization detector) using Shimadzu GC 2010 Plus gas chromatograph with a flame ionization detector (Shimadzu Corporation, Japan).

Vitamin D. Vitamin D was determined by a reverse phase high performance liquid chromatography (HPLC) with $100 \%$ acetonitrile as a mobile phase. For HPLC analysis Shimadzu Nexera X2 liquid chromatograph with Ascentis ${ }^{\circledR}$ C18 (150 mm x 4.6 mm I.D., $5 \mu \mathrm{m}$ particles) column and UV detector with $290 \mathrm{~nm}$ wavelength was used (CEN, 2008; Matilla et al., 1992).

Lipids and proteins. Total lipid and crude protein content were determined in the mayonnaise samples according to the method described in Horwitz (2011) work.

\section{Sensory evaluation}

Acceptance of mayonnaise sensory properties (yellow colour, egg smell, viscosity, egg taste, sour taste and creaminess) was evaluated using the 5 point hedonic scale ( 5 - extremely like, 3 - neither like nor dislike, 1 - extremely dislike) based on ISO 4121:2003 (ISO, 2003). 33 trained panelists from Latvia University of Agriculture at Faculty of Food Technology students and staff took part in this study. Mayonnaise samples $(35 \pm 3 \mathrm{~g})$ were filled in transparent plastic glasses, samples were left for 30 minutes at room temperature before evaluation. Mayonnaise samples were coded with three-digit random numbers and presented to the panelists. Orders of sample serving were completely randomized. Warm black tea was provided to cleanse the palate between two samples.

\section{Statistical analysis}

The results (mean, standard deviation, $P$ value) were processed by mathematical and statistical methods. All physical and chemical analyses were done at least in three replicates. Data were subjected to one-way analysis of variance (ANOVA) by Microsoft Office Excel (2007) significance was defined at $\mathrm{p}<0.05$. 


\section{Results and Discussion}

Physical and chemical properties of mayonnaise samples are presented in Table 2. The results show that there is no significant difference $(\mathrm{p}>0.05)$ in mayonnaise $\mathrm{pH}$. The $\mathrm{pH}$ of experimental mayonnaise samples with different egg yolk oil concentration was in a range from $4.05 \pm 0.02$ to $4.07 \pm 0.01$, which is within $3.5-4.5$ needed to control microbiological spoilage (Radford \& Board, 1993). This low $\mathrm{pH}$ is obtained by acetic acid from vinegar. Vinegar addition is also responsible for flavor development in mayonnaise (Depree \& Savage, 2001). Total lipid content of mayonnaise sample with $7 \%$ of egg yolk oil was higher than in the control, $1 \%$ and $3 \%$ egg yolk oil mayonnaise $(\mathrm{p}<0.05)$, but there was no difference between $5 \%$ and $7 \%$ EYO mayonnaise samples. Total lipid content in all mayon-

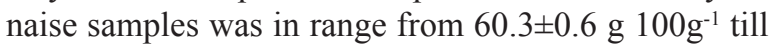

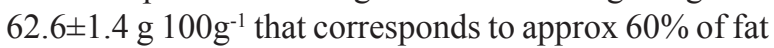
content calculated in mayonnaise recipes.

Table 2

\section{The $\mathbf{p H}$, viscosity, lipids, protein and D vitamin concentration of mayonnaise with different egg yolk oil (EYO) content}

\begin{tabular}{|l|l|l|l|l|l|}
\hline Sample & $\mathrm{pH}$ & Viscosity, cP & $\begin{array}{l}\text { Lipids, } \\
\mathrm{g} \mathrm{100 \textrm {g } ^ { - 1 }}\end{array}$ & $\begin{array}{l}\text { Protein, } \\
\mathrm{g} 100 \mathrm{~g}^{-1}\end{array}$ & $\begin{array}{l}\text { D vitamin, } \\
\mu \mathrm{g} \mathrm{kg}^{-1}\end{array}$ \\
\hline Control & $4.06 \pm 0.02^{\mathrm{a}}$ & $476.2 \pm 1.5^{\mathrm{a}}$ & $60.3 \pm 0.6^{\mathrm{a}}$ & $1.68 \pm 0.12^{\mathrm{a}}$ & $<0.1^{\mathrm{a}}$ \\
\hline EYO 1\% & $4.05 \pm 0.01^{\mathrm{a}}$ & $444.8 \pm 2.7^{\mathrm{b}}$ & $60.8 \pm 0.9^{\mathrm{a}}$ & $1.38 \pm 0.04^{\mathrm{b}}$ & $<0.1^{\mathrm{a}}$ \\
\hline EYO 3\% & $4.06 \pm 0.01^{\mathrm{a}}$ & $398.4 \pm 1.3^{\mathrm{c}}$ & $60.7 \pm 0.6^{\mathrm{a}}$ & $1.40 \pm 0.13^{\mathrm{b}}$ & $2.4 \pm 0.2^{\mathrm{b}}$ \\
\hline EYO 5\% & $4.07 \pm 0.01^{\mathrm{a}}$ & $210.0 \pm 1.2^{\mathrm{d}}$ & $61.1 \pm 1.1^{\mathrm{ab}}$ & $1.41 \pm 0.09^{\mathrm{b}}$ & $2.3 \pm 0.2^{\mathrm{b}}$ \\
\hline EYO 7\% & $4.06 \pm 0.02^{\mathrm{a}}$ & $170.0 \pm 1.6^{\mathrm{e}}$ & $62.6 \pm 1.4^{\mathrm{b}}$ & $1.38 \pm 0.09^{\mathrm{b}}$ & $5.6 \pm 0.6^{\mathrm{c}}$ \\
\hline
\end{tabular}

*Values, marked with the same subscript letters in rows, are not significantly different $(\mathrm{p}>0.05)$.

The protein content of mayonnaise samples with different egg yolk oil concentrations was from $1.38 \pm 0.04$

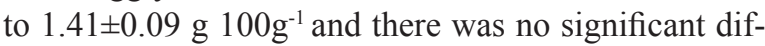
ference $(p>0.05)$ in protein content among these samples. The higher protein content in the control sample was caused by proteins from egg yolk powder, which was added to the control sample at dosage of $1 \%$.

The addition of egg yolk oil has a significant influence $(p<0.05)$ on mayonnaise viscosity. By increasing the egg yolk oil content, the viscosity of mayonnaise decreased. The control sample of mayonnaise has the highest viscosity $(476.2 \pm 1.5 \mathrm{cP})$ from all samples. The higher viscosity of control sample can be explained by higher emulsification properties caused by egg yolk powder proteins (Alleoni, 2006; Stadelman, 1999).

Only a few products naturally contain vitamin D eggs is one of them. Vitamin D is a lipid soluble vitamin and it locates in egg yolk. Vitamin D content in egg yolk depends on the layer supplement with vitamin D through feed and varies from 34 to $58 \mu \mathrm{g} \mathrm{kg}^{-1}$ (Schmid
\& Walther, 2013). Depending on fat content of egg yolk and extraction procedure, the calculated vitamin D content in egg yolk oil can be 3.0-3.5 times higher than in yolk. Addition of egg yolk oil at 3, 5 and 7\% enriches mayonnaise with vitamin D. For control sample (with egg yolk powder) and mayonnaise sample with $1 \%$ of egg yolk additive vitamin D content was bellow detection limits $-<0.1 \mu \mathrm{g} \mathrm{kg}^{-1}$. According to European Food Information Council, the recommended daily amount for vitamin D in the European Union is $5 \mu \mathrm{g}$. $50 \mathrm{~g}$ of mayonnaise with $7 \%$ of added egg yolk oil can provide about $0.28 \mu \mathrm{g}$ of vitamin D or $5.6 \%$ of recommended daily intake.

Colour of mayonnaise plays an important role in consumer's preference. Intensive yellow colour of mayonnaise usually associates with high content of eggs meaning additional nutritional and biological benefits and taste. The results of colour CIE L*a* ${ }^{*}{ }^{*}$ measurements and $\Delta \mathrm{E}$ of mayonnaise samples are presented in Table 3. 
The colour CIE $L * a * b *$ values of mayonnaise with different egg yolk oil (EYO) content

\begin{tabular}{|c|c|c|c|c|}
\hline \multirow{2}{*}{ Samples } & \multicolumn{3}{|c|}{ CIE L*a ${ }^{*} b^{*}$ values } & \multirow[t]{2}{*}{$\Delta \mathrm{E}$} \\
\hline & $\mathrm{L}^{*}$ & $a^{*}$ & $b^{*}$ & \\
\hline Control & $87.14 \pm 1.10^{\mathrm{a}}$ & $0.69 \pm 0.45$ & $7.68 \pm 0.92^{\mathrm{a}}$ & 0 \\
\hline EYO 1\% & $85.62 \pm 0.71^{\mathrm{a}}$ & $0.23 \pm 0.35$ & $8.45 \pm 0.74^{\mathrm{a}}$ & $2.30 \pm 0.73^{\mathrm{a}}$ \\
\hline EYO 3\% & $85.14 \pm 0.74^{\mathrm{a}}$ & $0.18 \pm 0.27$ & $13.03 \pm 0.81^{b}$ & $5.74 \pm 0.41^{\mathrm{b}}$ \\
\hline EYO 5\% & $81.40 \pm 0.46^{\mathrm{b}}$ & $0.27 \pm 0.19$ & $17.72 \pm 0.15^{\mathrm{c}}$ & $11.61 \pm 1.04^{\mathrm{c}}$ \\
\hline EYO 7\% & $79.66 \pm 0.15^{\mathrm{b}}$ & $0.52 \pm 0.05$ & $22.91 \pm 0.17^{\mathrm{d}}$ & $17.02 \pm 1.28^{\mathrm{d}}$ \\
\hline
\end{tabular}

* Values, marked with the same subscript letters in rows, are not significantly different $(\mathrm{p}>0.05)$.

Mayonnaise is an oil-in-water emulsion which contains both dispersed and a continuous phase with the interfaces between these two phases. These interfaces scatter the light when it passes through the emulsion. Thus, emulsions have a cloudy or even white appearance (if all light is scattered equally) (McClements, Chantrapornchai \& Clydesdale, 1998). The high value of $L^{*}$, from $79.66 \pm 0.15$ till $87.14 \pm 1.10$, indicates very light to white colour of mayonnaise samples. There was a significant $(\mathrm{p}<0.05)$ decrease of $\mathrm{L}^{*}$ value among mayonnaise samples with addition of 3, 5 and $7 \%$ of egg yolk oil. We determined the significant difference $(p<0.05)$ in yellow colour (as a positive value of $\left.b^{*}\right)$ within all mayonnaise samples with increase of egg yolk oil concentration. A strong correlation $(r=0.999)$ of egg yolk oil concentration and yellow colour intensity of mayonnaise was determined (Figure 1). The calculated $\Delta \mathrm{E}$ values showed significant difference $(\mathrm{p}<0.05)$ among all mayonnaise samples.

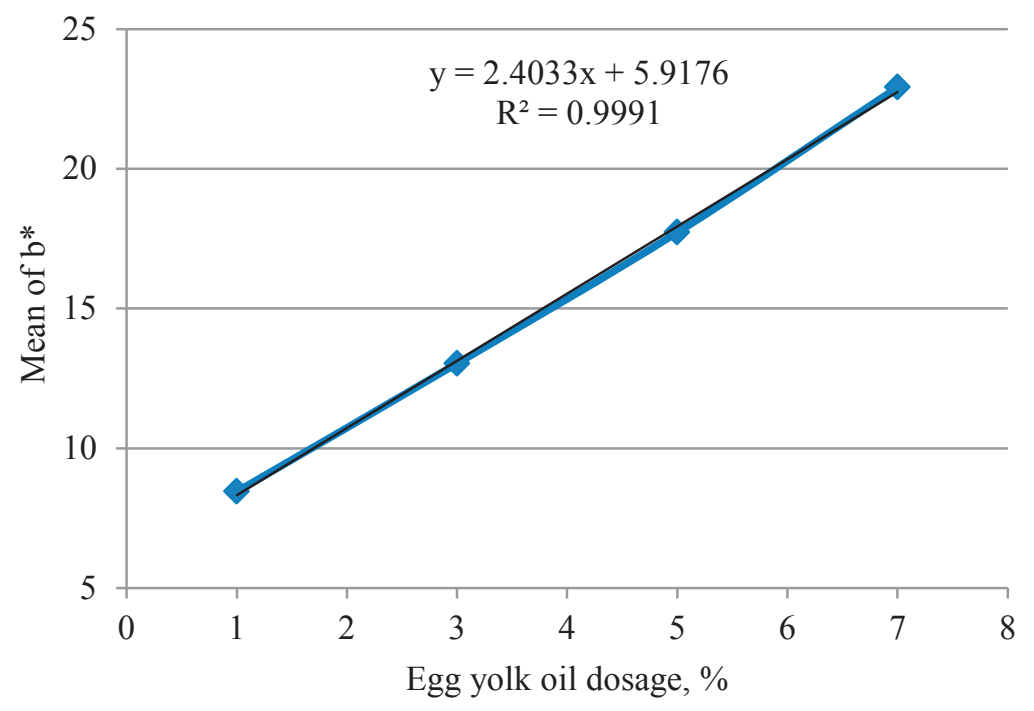

Figure 1. The influence of egg yolk oil concentration on yellow colour of mayonnaise. 
Mayonnaise contains $60-70 \%$ of vegetable oil, which is rich in unsaturated fatty acids. In this study sunflower oil with high linoleic acid content (65.09 \pm 0.08 g $100 \mathrm{~g}^{-1}$ ) was used for preparation of mayonnaise (Table 4). The fatty acid profile of egg yolk oil depends on laying hen feed content. Increasing of unsaturated fatty acid content in hen's feed results in an increase of egg unsaturated fatty acids (Lewis, Seburg \& Flanagan, 2000). Mayonnaise with addition of egg yolk oil has a combination of sunflower oil and egg yolk oil fatty acids.

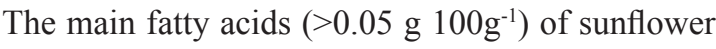
oil and egg yolk oil, and fatty acid content of mayonnaise samples are presented in Table 4.

Fatty acids of egg yolk oil and sunflower oil compensate each other due to increase or decrease of their content in mayonnaise. The main point is that addition of egg yolk oil enriches mayonnaise with docosahexaenoic acids, but the increase is noticeable only when egg yolk oil is added at the dosage of $5 \%$ and $7 \%$. The dosage $1 \%-7 \%$ of egg yolk oil in mayonnaise is too low to significantly influence fatty acids content of mayonnaise.

The sensory evaluation data shows insignificant difference $(p>0.05)$ in the degree of acceptance of egg taste, aroma and sour taste of mayonnaise samples. According to the 5 point hedonic scale, egg aroma, egg taste and sour taste of mayonnaise samples were rated in the range from 3 (neither like nor dislike) to 4 (like moderately).

The amount of added egg yolk oil significantly influenced $(p<0.05)$ the degree of acceptance of mayonnaise viscosity, yellow colour and creaminess (Figure 2).

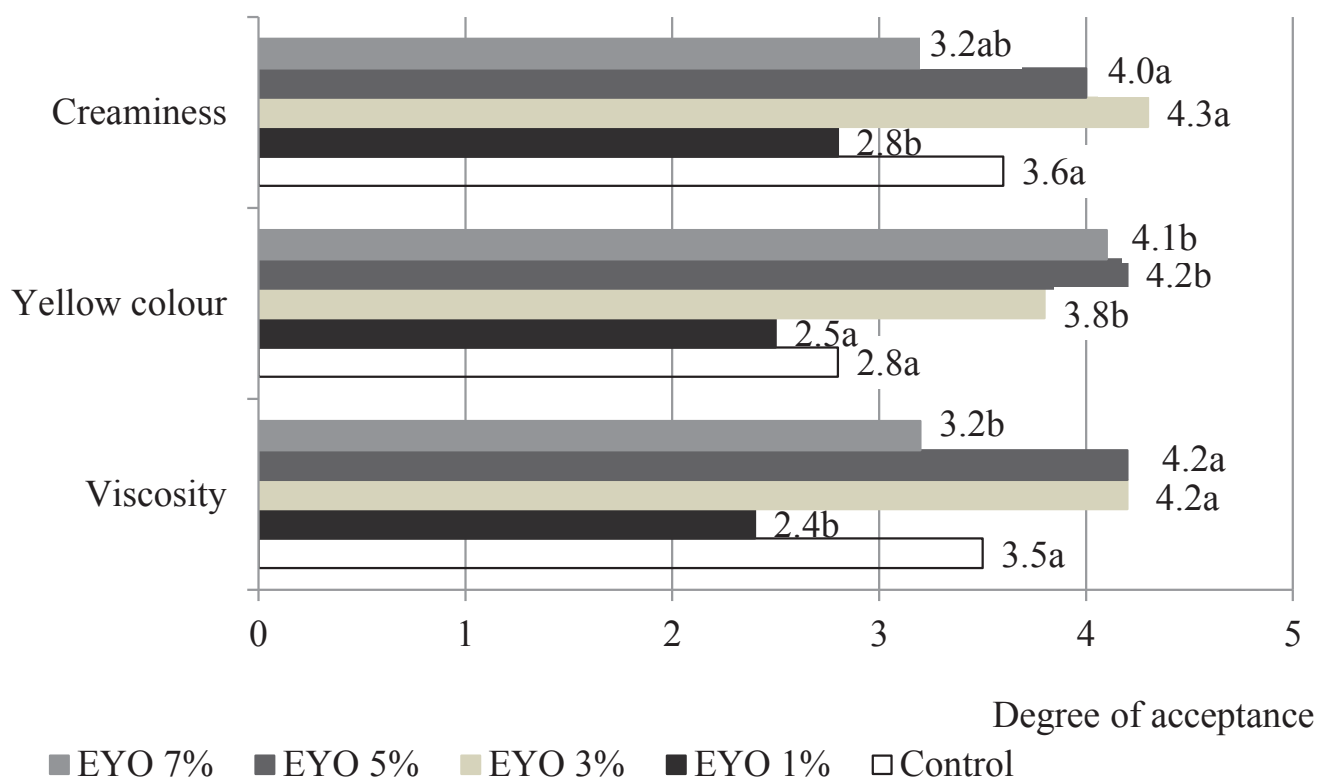

Figure 2. The acceptance degree of sensory properties of mayonnaise with egg yolk oil. * Values, marked with the same subscript letters, are not significantly different $(\mathrm{p}>0.05)$. 
Fatty acid content of mayonnaise with different egg yolk oil (EYO) content, $\mathrm{g} \mathbf{1 0 0 g}^{-1}$

\begin{tabular}{|c|c|c|c|c|c|c|c|}
\hline \multirow[t]{2}{*}{ Fatty acid } & \multirow{2}{*}{$\begin{array}{l}\text { Sunflower } \\
\text { oil }\end{array}$} & \multirow{2}{*}{$\begin{array}{l}\text { Egg yolk } \\
\text { oil }\end{array}$} & \multicolumn{5}{|c|}{ Mayonnaise samples } \\
\hline & & & Control & EYO 1\% & EYO 3\% & EYO 5\% & EYO 7\% \\
\hline $\begin{array}{l}\text { Palmitic acid } \\
(\mathrm{C} 16: 0)\end{array}$ & $7.00 \pm 0.03$ & $24.08 \pm 0.04$ & $4.25 \pm 0.02$ & $4.20 \pm 0.04$ & $4.25 \pm 0.02$ & $4.48 \pm 0.03$ & $4.94 \pm 0.01$ \\
\hline $\begin{array}{l}\text { Palmitoleic acid } \\
\text { (C16:1) }\end{array}$ & $0.07 \pm 0.01$ & $5.35 \pm 0.02$ & $0.10 \pm 0.01$ & $0.10 \pm 0.02$ & $0.14 \pm 0.01$ & $0.20 \pm 0.02$ & $0.27 \pm 0.02$ \\
\hline $\begin{array}{l}\text { Stearic acid } \\
(\mathrm{C} 18: 0)\end{array}$ & $3.50 \pm 0.02$ & $6.53 \pm 0.04$ & $2.09 \pm 0.02$ & $2.11 \pm 0.02$ & $2.12 \pm 0.03$ & $2.20 \pm 0.02$ & $2.31 \pm 0.01$ \\
\hline $\begin{array}{l}\text { Oleic acid } \\
(\mathrm{C} 18: 1)\end{array}$ & $21.77 \pm 0.08$ & $48.05 \pm 0.06$ & $13.71 \pm 0.04$ & $14.21 \pm 0.06$ & $14.28 \pm 0.07$ & $14.60 \pm 0.04$ & $15.62 \pm 0.04$ \\
\hline $\begin{array}{l}\text { Linoleic acid } \\
(\mathrm{C} 18: 2)\end{array}$ & $65.09 \pm 0.08$ & $11.12 \pm 0.03$ & $38.15 \pm 0.05$ & $38.10 \pm 0.08$ & $37.68 \pm 0.05$ & $37.53 \pm 0.08$ & $37.27 \pm 0.10$ \\
\hline $\begin{array}{l}\alpha \text {-linolenic acid } \\
(\mathrm{C} 18: 3)\end{array}$ & $0.13 \pm 0.02$ & $1.44 \pm 0.02$ & $0.05 \pm 0.02$ & $0.06 \pm 0.01$ & $0.07 \pm 0.01$ & $0.09 \pm 0.01$ & $0.11 \pm 0.02$ \\
\hline $\begin{array}{l}\text { Eicosadienoic } \\
\text { acid (C20:2) }\end{array}$ & $0.67 \pm 0.02$ & $0.11 \pm 0.01$ & $0.02 \pm 0.01$ & $0.03 \pm 0.01$ & $0.02 \pm 0.01$ & $0.02 \pm 0.01$ & $0.05 \pm 0.01$ \\
\hline $\begin{array}{l}\text { Docosahexaenoic } \\
\text { acid (C22:6) }\end{array}$ & - & $0.76 \pm 0.01$ & - & - & - & $0.02 \pm 0.01$ & $0.03 \pm 0.01$ \\
\hline
\end{tabular}

Results of the hedonic scores showed the panellists preference for the sensory properties of mayonnaise with $3 \%$ and $5 \%$ egg yolk oil content. The lowest score of sensory properties (viscosity, yellow colour and creaminess) were determined for the sample with $1 \%$ of egg yolk oil content.

\section{Conclusions}

1. Egg yolk oil at $1-7 \%$ concentration has no influence $(p>0.05)$ on mayonnaise $\mathrm{pH}$, lipid and protein content.

2. An increase in egg yolk oil content decreases the viscosity of mayonnaise.

3. Increasing amount of egg yolk additive results in more intensive yellow colour of mayonnaise.

4. Additions of egg yolk oil at $5 \%$ and $7 \%$ concentration enrich mayonnaise with vitamin D and docosahexaenoic acid.

5. Sensory evaluation of mayonnaise samples shows panellists' preference for mayonnaise with 3\% and $5 \%$ egg yolk oil additive.

\section{References}

1. Abu-Salem, F. M. \& Abou-Ara, A. A. (2008). Chemical, microbiological and sensory evaluation of mayonnaise prepared from ostrich eggs. Grasas y Aceites, 59(4), 352-360. DOI: 10.3989/ gya.2008.v59.i4.529.

2. Alleoni, A. C. C. (2006). Albumen protein and functional properties of gelation and foaming. Scientia Agricola, 63(3), 291-298. DOI: 10.1590/ S0103-90162006000300013.

3. Amin, M. H., Elbeltagy, A. E., Mustafa, M. \& Khalil, A. H. (2014). Development of low fat mayonnaise containing different types and levels of hydrocolloid gum. Journal of Agroalimentary Processes and Technologies, 20(1), 54-63. ISSN:2068-9551.

4. European Committee for Standardization (2008). Foodstuffs - Determination of vitamin D by high performance liquid chromatography-Measurement of cholecalcipherol (D3) and ergocalcipherol (D2). EN12821. European Committee for Standardization, Rue de Stassart, 36, B-1050, Bruxelles. 
5. Depree, J. A. \& Savage, G. P. (2001). Physical and flavour stability of mayonnaise. Trends in Food Science \& Technology, 12, 157-163. DOI: 10.1016/S0924-2244(01)00079-6.

6. Egg nutritional council (2014). Position Statement for Healthcare Professionals. The role of eggs in healthy diet. Australia: Australian Egg Corporation Ltd.

7. Herald, T. J., Abugoush, M. \& Aramoouni, F. (2009). Physical and sensory properties of egg yolk and egg yolk substitutes in a model mayonnaise system. Journal of Texture Studies, 40(6), 692 709. DOI: $10.1111 / j .1745-4603.2009 .00206 . x$.

8. Holick, M. F. (2007). Vitamin D deficiency. The New England Journal of Medicine, 357, 266-281. DOI: 10.1056/NEJMra070553.

9. Horwitz, W. ed. (2011). Official Methods of Analysis of Association of Official Analytical Chemists International. Gaithersburg, AOAC International.

10. Huopalahti, R., Lopez-Fandino, R., Anton, M. \& Schade, R. (2007). Bioactive egg compounds. Heidelberg, Springer.

11. International Organization for Standardization (1990). Animal and vegetable fats and oils - Analysis by gas chromatography of methyl esters of fatty acids. ISO 5508.

12. International Organization for Standardization (2003). Sensory analysis - Guidelines for the use of quantitative response scales. ISO 4121:2003.

13. International Organization for Standardization (2011). Animal and vegetable fats and oils - Gas chromatography of fatty acid methyl esters - Part 2: Preparation of methyl esters of fatty acids. ISO 12966-2.

14. Joint International Organization for Standardization/International Commission on Illumination Standard. (2007). CIE Colorimetry - Part 4: 1976 L*a*b* Colour Space. ISO 11664-4:2008(E)/CIE S 014-4/E:2007.

15. Karas, R. Skvarča, M. \& Žlender, B. (2002). Sensory quality of standard and light mayonnaise during storage. Food Technology and Biotechnology, 40(2), 119-127. UDC 664.346:351.773.
16. Kovalcuks, A. (2014). Purification of egg yolk oil obtained by solvent extraction from liquid egg yolk. In Annual 20th international scientific conference Research for Rural Development, 21-23 May 2014 (pp. 142-147). Jelgava, Latvia: Latvia University of Agriculture.

17. Layman, K. L. \& Rodriguez, N. R. (2009). Egg protein as a source of power, strength and energy. Nutrition Today, 44(1), 43-48. DOI: 10.1097/ NT.0b013e3181959cb2.

18. Lewis, N. M., Seburg, S. \& Flanagan, N. L. (2000). Enriched eggs as a source of N-3 polyunsaturated fatty acids for humans. Poultry Science, 79, 971-974. DOI: 10.1093/ps/79.7.971.

19. Matilla, P. H., Piironen, V., Bäckman, C., Asunmaa, A., Uusirauva, E. \& Koivistoinen, P. (1992). Determination of vitamin D3 in egg yolk by highperformance liquid chromatography with diode array detection. Journal of Food Composition and Analysis, 5, 281-190. DOI: 10.1016/08891575(92)90062-O.

20. McClements, D. J., Chantrapornchai, W. \& Clydesdale, F. (1998). Prediction of food emulsion color using light scattering theory. Journal of Food Science, 63, 935-939. DOI: 10.1111/j.13652621.1998.tb15827.x.

21. Radford, S. \& Board, R. (1993). Review: Fate of pathogens in home-made mayonnaise and related products. Food Microbiology, 10(4), 269-278. DOI: 10.1006/fmic.1993.1031.

22. Schmid, A. \& Walther, B. (2013). Natural vitamin $\mathrm{D}$ content in animal products. Advances in Nutrition, 4(4), 453-462. DOI: 10.3945/an.113.003780.

23. Schneider, M. (2001). Phospholipids for functional food. European Journal of Lipid Science and Technology, 103, 98-101. DOI: 10.1002/14389312(200102).

24. Stadelman, W. J. (1999). The incredibly functional egg. Poultry Science, 78, 807-811. DOI: 10.1093/ ps/78.6.807.

25. Tan, J. W. \& Joshi, P. (2014). Egg allergy: an update. Journal of Pediatrics and Child Health, 50(1), 11-15. DOI: 10.1111/jpc.12408. 